\title{
Camaraderie, mentorship, and manhood:
}

\section{Contemporary Indigenous identities among the A'uwẽ (Xavante) of Central Brazil}

James R. Welch ${ }^{1}$

${ }^{1}$ Escola Nacional de Saúde Pública, Fundação Oswaldo Cruz, Rua Leopoldo Bulhões 1480, Rio de Janeiro, RJ, 21041-210 Brazil (welch@ensp.fiocruz.br)

August 16, 2021

\begin{abstract}
Rites of passage and associated social processes and morphologies can foster a sense of shared purpose, fraternity, and dedication to community through the common experiences of group trials and commitment. A'uwẽ (Xavante) age organization entails the social production of manhood through a privileged form of male camaraderie constructed through age sets and mentorship, rooted in the shared experience of rites of passage and coresidence in the pre-initiate boys' house. This process is central to how A'uwẽ men understand themselves, their social relations with certain delineated segments of society, and their ethnic identity. It is a basic social configuration contributing to the maintenance of A'uwẽ social and ethnic belonging in contemporary times. Ethnography of Amazonia should expand its reach to consider the contributions of age organization and ritualized camaraderie to social and ethnic identity.
\end{abstract}

Keywords Indigenous peoples; ethnic identity; age organization; rites of passage; A'uwẽ (Xavante); Brazil

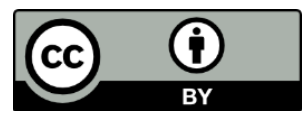

This paper is licensed under a Creative Commons Attribution 4.0 International (CC BY 4.0) Public License.

\section{Cite as:}

Welch, James R. 2021. "Camaraderie, Mentorship, and Manhood: Contemporary Indigenous Identities Among the A'uwẽ (Xavante) of Central Brazil." SocArXiv. August 20. doi:10.31235/osf.io/b74fg. 


\section{Indigenous identity and the moral equivalence of war}

In his 1906 lecture entitled "Proposing the Moral Equivalent of War," William James briefly set aside the costs and repugnancy of war to propose the possibility of peaceful alternatives that would promote sustained political unity and civic virtue as effectively as war. His answer to this call resides in a sense of service and collectivity among members of society (James 1910). My undergraduate Social and Cultural Anthropology teacher, George Spindler, proposed in class that rites of passage in diverse cultures can take on this role as moral equivalents of war. They can foster a sense of common purpose, fraternity, and dedication to community through the common experience of shared trials, or other forms of social constriction. Similar lines of scholarly reasoning attribute special kinds of community and camaraderie to such experiences as military service (Armstrong 2013; Burk 1999), college fraternities (Syrett 2009), fraternal orders (Chrisman 1974), and sports (Senecal 2017; Weedon 2015).

If rites of passage and other configurations encouraging social constriction among groups or cohorts can engender these kinds of civic moralities among participants, then the social processes and morphologies that anticipate, shape, and succeed the rites themselves should also be considered part of the package. Participants in rites of passage and their associated social complexes may experience a shared sense of hardship that encourages bonding between peers as well as integral pleasurable emotive experiences such as group commitment and camaraderie. Such affective experiences may be especially strong among peers but may also generate a sense of civic belonging through their extension to society at large, and thus contribute to formulations of group identity. What Van Gennep (1960) characterized as a ritualized exclusion from society during the liminal phase of pre-initiation anticipating advancement into adulthood is viewed here as production of an alternative social life imbued with unusual trust and solidarity. This alternative social life can serve to create extraordinary lifelong bonds not only among ceremonial peers, but also between them and older groups of people responsible for their successful passage. Thus, the moral equivalency of war involves not only shared strife but also intimate group sentiments that bind a person nearing manhood to his ceremonial peers and mentors. Furthermore, these sentiments transform ritual experiences of hardship into cherished opportunities to act in service and dedication, even suffering, for one's group, one's successors, or society in general.

Sociologists have debated about sources of solidarity that bind society together and stimulate enduring sources of human social identity, whether it by through religion, systems of exchange, or persisting cultural institutions (Durkheim 1915; Mauss 1966; Merton 1957). These earlier ideas foreshadow contemporary literature investigating the maintenance of Indigenous identity in contempoary contexts (Erickson 2008; Graham 2005; Lumby 2010; Simpson 2004), although rarely do they address rites of passage or associated social morphologies as part of this process.

In recent decades, new rites of passage have been used as interventions to stimulate identity learning, teach social skills, promote cultural values, and ultimately bring about social change (Brookins 1996). Among Indigenous communities worldwide there is a recent resurgence of interest in fortifying intergenerational transfer of knowledge and values considered traditional, as well as applying them in practice (Battiste and Henderson 2000; Simpson 2004). In some cases, a process of reindigenization follows greater exposure to national 
and international discourses regarding Indigenous identity and environmental conservation (Jackson and Ramírez 2009). The ensuing ethnographic documentation of how A'uwẽ camaraderie of mentorship comes into being through the lengthy collective process of creating men, which includes but is not limited to rites of passage, demonstrates how its manifestation among a group of boys and men engenders individual commitment to some traditionalist ethnic identity values especially in contemporary times.

Although much of recent ethnographic literature on Amazonia has emphasized the social and cosmological correlates of affinal and consanguineal relations or nature versus culture conceptualizations (Ramos 2012; Viveiros de Castro 1998, 2002), emergent scholarship has attributed the creation of a sense of identity, amicability, and friendship between individuals and within society to processes of commensality, co-working, shamanic competition, trading partnerships, and mystical associations (Fausto 2002; McCallum 2003; Santos-Granero 2007). Some Gê speaking societies, including the A'uwẽ, have formal friendships, which are a distinct ritual formulation not addressed in this paper (Giraldin 2011). Different from but complementing these examples is a privileged configuration of group friendship (camaraderie) formed through the social production of adult men that can result from shared ritual challenges in conjunction with enduring relationships of indulgence and confidence among protégés and between protégés and their mentors. Thus, in some Amazonian societies with sodalities, the social process involved in transforming boys into men can serve as a moral equivalent to war it bonds members of a cohort in ways that transcend casual friendship and, through this camaraderie, commits them as a group to society at large for the rest of their lives. It is therefore also a basic dynamic contributing to ethnic identity among males. Differently from some traditional representations of ethnic identity formation (Barth 1969), this view of the construction of ethnic identity does not emphasize external points of reference, such as those involving interethnic contact and conflict (Fearon and Laitin 2000; Thurairajah 2020).

Due to its focus on the social production of men by means of something akin to a men's cult, this discussion intersects with the field of manhood and masculinity studies. Its insertion in this field derives from its focus on what "men think and do to be men" (Gutmann 1997, 386), but does not engage this literature to ascertain what comprises (hyper) manliness or what differentiates men from women. I do not address here A'uwẽ iconic masculine virility, which other scholars have argued is inherent to their society or created through scientific writing (Dent 2020; Overing 1989). In my framing, manhood is a social process beginning in boyhood that serves to transform youthful into mature behaviors and points of view. Thus, manhood is not static or uniform, but rather produced and reproduced individually throughout one's life. I am not as concerned with the performance of masculinity (Gregor 1979; Herzfeld 1985) as I am with the social processes that are understood to produce good and proper adult men, and thereby promote social well-being. In this sense, my approach is aligned with Keesing's (1982) position that in Melanesia and Amazonia, rites of passage place emphasis on the social rather than natural production of men from boys, which is a task only men can perform.

My ethnographic basis includes 16 years of intermittent fieldwork in three Indigenous villages, Pimentel Barbosa, Etênhiritipá, and Novo Paraíso, pertaining to the A'uwẽ ethnic group, also known as Xavante or Shavante. I use age organization as a lens into their notions of how socially producing men and manhood is accomplished through a special form of male camaraderie. My principal ethnographic aim is to show how multiple social configurations that 
A'uwẽ men understand promote the process of transforming boys into men is central to how they understand themselves, their social relations with certain privileged segments of society, and their own ethnic identity. How these people understand age relations bears upon how they view good and beautiful ways of adult living, which involve cultural traditionalism regarding behaviors and forms of interacting with one another.

The A'uwẽ are iconic in the literature on Indigenous lowland South America social organization, health, ecology, and history. First known as a dangerous people that impeded development of Brazil's interior region, through their decades-long collaborations with diverse scholars they became one of the most studied Indigenous groups in Brazil. Maybury-Lewis's (1967) structuralist approach to A'uwẽ social organization contributed to early recognition that this and other Gê-speaking groups have highly formalized social morphologies and ceremonial activities. More recent anthropological scholarship helped draw attention to major political, environmental, demographic, economic, and health challenges that the A'uwẽ endured in recent decades, which are key to understanding the persistence of Indigenous A'uwẽ identity in contemporary times (Coimbra Jr et al. 2002; Garfield 2001; Graham 1995; Flowers 1983; Welch et al. 2013).

My ethnographic approach is highly influenced by how I was received by the A'uwẽ at Etênhiritipá village in 2004. When I first arrived I was incorporated into the êtẽpá secular age set, whose members were in their late teens (despite my age at the time, which was 36) and belonged to the novitiate adulthood (dahi'wa or ritei'wa) secular age grade. These insertions created for me a network of family and friends, and a series of social positions that both limited and expanded my access to certain aspects of society. For example, my maleness allowed me to participate in male camaraderie but greatly reduced my ability to ascertain female perspectives. Rather than considering these associations a hinderance to my ethnographic work, I understand them to have been essential to my ability to understand certain viewpoints and frames of reference. Also, entering the system as a classificatory young adult has given me the opportunity to participate in the transformations of activities and relationships as my age groups grew older over the years, a process allied with literature addressing the social construction of the public person in Amazonia (Seeger, DaMatta, and Viveiros de Castro 2019).

During the initial years, my identity as a male member of the novitiate adult age grade was also extremely important to how I fit socially into the community. My male age-set peers made gracious efforts to include me in their activities and offer their assistance with my research endeavors. Some of these peers became my closest friends in the community, sharing with me their personal concerns and relying on me to keep their business secret from the rest of the community and the public. Perhaps more than anything else, learning and keeping my age set's secrets transformed my membership in the novitiate adult age grade from a formal designation to an experience that taught me the significance of camaraderie among the A'uwẽ.

Through the influential work of anthropologist Maybury-Lewis $(1967,1979)$, the A'uwẽ came to be recognized as a South American example of an Indigenous society with a formal age group system. The system identified by Maybury-Lewis may be considered secular because it does not involve activities the A'uwẽ consider to be spiritual. This secular age group system is the focus of the present article. A different age group system whose principal interest is spiritual, according to A'uwẽ points of view, was subsequently recognized and has been addressed elsewhere (Welch 2010). Formal age grades in these relatively uncommon age group systems 
(both secular and spiritual) differ from the informal age grades that are present in all societies and mark stages of the human life cycle based on individualistic and subjective criteria. The spiritual age group system marks social age in an analogous manner to the secular system, although in a categorically different domain of social relations. Both systems reckon age socially rather than biologically, chronologically, or psychologically. They are characterized by age sets (cohorts or classes) that pass through a series of formal age grades (ranks) by means of public ceremonial events or rites of passage (Bernardi 1985; Prins 1953; Stewart 1977). The following sections, organized by formal age grades, show how the A'uwẽ secular age set system involves social dynamics, rites of passage, and identity correlates that contribute to the maintenance of A'uwẽ social and ethnic belonging in contemporary times.

\section{Pre-initiation (wapté)}

The A'uwẽ term wapté has been translated elsewhere as male "adolescent" (Giaccaria and Heide 1984, 150), "bachelor" (Graham 1995, 96; Maybury-Lewis 1967, 105-14), and "preinitiate" (Graham 1995, 97). According to my ethnographic observations and interviews, the term wapté was used systematically for males from the moment they were ritually inducted into a pre-initiate house $(h \ddot{)})$, where they resided in symbolic seclusion for up to four or five years, until their collective ceremonial initiation as an age set or cohort into adulthood. From the moment of their induction into the pre-initiate house, they ceased to be members of the informal age grade to which they previously belonged, whether that happened to be boy (watebremi ) or male adolescent (ai'repudu). Thus, for young males, the informal age grade sequence ends upon induction to the pre-initiate house and only resumes, as we will see below, in advanced age (Figure 1). No young females were ever called wapté which was, according to my interlocuters, because they never resided in the pre-initiate house. Females do participate with wapté boys in mutual age sets but are not designated as wapté because they remain living at home during this phase of the life cycle.

The distinction between the classificatory informality of childhood ( $a$ 'uté), boyhood, and male adolescence and the formality of pre-initiation is not only theoretical but also reflects the explicit emic recognition that pre-initiate status is predicated on participation in public rites of passage, independent of one's stage of personal biological development. Participating in these strenuous rites of passage is considered a fundamental means of gaining strength and maturing physically and emotionally, a process that contributes to the well-being of all individuals involved. While their male age set peers are called pre-initiates, female members of the age set are not yet designated by a formal age grade term. During this phase of life, they continue to be called by informal age grade terms, such as female child (ba'õno), female adolescent (azarudu), and married woman without child (adabá).

Consistent with Maybury-Lewis, I distinguished between age-set inauguration ceremonies (deza'hi'höri), in which boys of similar ages are assigned to an age set and thereby become pre-initiates, and subsequent induction rites (wapté rõiwĩhã), which mark their entrance into the pre-initiate house and designation as wapté (Maybury-Lewis 1967). However, my data contradict some of the organizational implications of his account. For example, as I observed, the age-set inauguration ceremony involves both boys and girls of similar ages, who are thereby all assigned to shared age sets. Thus, age sets are coed cohorts of similarly aged young people who participated in age-set inauguration ceremonies together. What distinguishes boys' from 
girls' experiences as new members of an age set is that boys but not girls coreside in the preinitiate house under the guidance of their male mentors, who belong to a moderately older age set.

Lopes da Silva (1986) and Giaccaria and Heide (1984) mention another term, heroi'wa, characterizing it as a transitional stage that separates pre-initiation from young manhood. Although the term is not included in most accounts of the formal male age grade sequence, it would appear from these authors' descriptions to be a brief and discrete category. My data confirm the use of heroi'wa ("initiand") and another term, watei'wa ("water splasher"), during the ceremonial stages leading up to boys' passage into manhood, as described below (cf. Giaccaria 2000; Giaccaria and Heide 1984; Maybury-Lewis 1967). There are no equivalents for girls of similar ages.

The first activity associated with the initiation rites that lead to passage into male adulthood is a mentor's group hunt in approximately May of the previous year (Welch 2015). The subsequent sequences of intensive initiation rites often last more than six months, from approximately March to August the next year. An endurance exercise (dasiwatei), held around March and lasting several weeks, involves the boys entering the river for considerable intervals throughout each day and night, vigorously splashing the surface of the water to produce synchronized plumes of water (Figure 2). It is an exhausting process that both tests and promotes physical and psychological endurance among boys. Exclusively during this "water-splashing" ceremony, the male participants are called watei'wa. This term no longer applies after the boys exit the river for the last time and proceed to the village, where an ear-piercing ceremony (daporezapú) is held that inscribes onto the male body one's advancement toward adulthood (girls' ears are not pierced). The beginning of the dasiwatei exercises also marks a terminological change from male pre-initiation to initiand. The more encompassing term heroi'wa is used until the end of the sequence of ceremonies that begin with ear-piercing and end with a wrestling match ( $\left.w a{ }^{\prime} i\right)$ some five days later. This wrestling match marks the end of male initiand status and the beginning of a transition to coed novitiate adulthood, a liminal phase in which no specific formal age grade term properly applies.

Although the published literature and common discourse often repeats that A'uwẽ boys spend five years in the pre-initiate house, my data suggest it is more accurate to say that about every five years another age set leaves the pre-initiate house (and is initiated into adulthood). Male coresidents ( $h \ddot{\prime}$ 'wa) may reside in the pre-initiate house from just a few days to as long as four or occasionally five years. The first time I visited the village, in May 2004, there were already 18 coresidents in the pre-initiate house. They were the first of their age set to enter the pre-initiate age grade, having been ritually inducted in August 2002, about one year after the previous group exited the pre-initiate house as they neared initiation into adulthood. Consequently, they were to be the only members of their age set to spend a full four years in coresidence. Members of this first contingent were called irõ'rada ("first penis sheath"), meaning they were the first to assume pre-initiate coresident status, which historically (but no longer) involved adopting the practice of wearing a penis sheath, the only precontact article of adult male clothing (Maybury-Lewis 1967). As the first contingent of their age set to be inducted into the pre-initiate house, these boys came to be known as the age set's eldest members and leaders. 
In November 2004, I witnessed the induction rites of a second group of 11 boys into the pre-initiate house. Members of his group were called dawawa'ĩrõ ("middle penis sheath") because they were the second of three primary staggered groups to enter the pre-initiate house. These rites lasted three days and involved a busy schedule of club fights (oi'o), wrestling matches, and log races (uiwede), leading up to a final presentation of the new inductees in the central plaza. Members of this newly inducted group immediately began sleeping in the preinitiate house with their older age-set mates. Girls did not participate in these induction rites and did not take up residence in the pre-initiate house. The third group to be inducted is called irõ 'te ("last penis sheath"). Occasionally a late fourth group (hödawa'ö’ha) or even a last-minute addition (ubranhowaha) immediately before initiation will be inducted. Thus, some boys reside in the pre-initiate house for very short periods of time, as little as a few days. All of the staggered induction groups graduate from the pre-initiate house together, shortly before a new group of boys and male adolescents, along with their female age-set mates, are ceremonially identified for inclusion in the next age set during an age-set inauguration ceremony.

Pre-initiates' mentors (danhohui'wa) are members of the second anterior (older) age set. Thus, having graduated from the pre-initiate house two cycles earlier, they are on average approximately 10 years older than their protégés. It is under their guidance that pre-initiate boys are said to be involved in the process of becoming adults. From the A'uwẽ perspective, the mentor-protégé relationship is the only correct configuration for educating boys and is considered a foundation for much of male adult sociality. The social relationship between mentors and their protégés (hö'wa nõri) is an essential part of the age set system both morphologically and experientially. Thus, it is intimately associated with how pre-initiate males learn to become adults and thereby contribute to the well-being of their age set associates, families, and communities.

Just as induction into the pre-initiate house is a public collective event that showcases male individual performance through competitions, being a pre-initiate coresident is seen as a process of individual and collective transformation. As one mature adult told me, living in the pre-initiate house is about boys learning to think like adults by "opening their minds" (darã si sãmra dahã). These boys are encouraged to behave themselves, which includes keeping quiet, remaining in proximity to their peers and mentors, and minding their own and nobody else's business. It is through this behavioral conformity that boys transform themselves into conscientious adults. Residence in the pre-initiate house is also about gaining a general education (Little 1949) relevant to living a responsible life as a young man, husband, and father.

The pre-initiate age grade is emblematic of male notions of traditionalism and good living specifically because it is widely recognized by men to be the primary socially orienting event in their own lives and the lives of all men, past and present. Novitiate men, mature men, elder men, and male ancestors alike are thought to share the experience of having left their natal households to join an age set of peers under the affectionate guidance of their mentors. It is that shared experience more than any other that gives A'uwẽ men a sense of historical continuity. Pre-initiates of all ages are thought to have been inducted into the pre-initiate house through the same rites of passage and to have been held to the same program of personal and collective development while there. In this sense, the pre-initiate age grade symbolizes tradition and historical continuity more specifically than any other age grade, including that of elders. 
In many contexts, elders also characterized the pre-initiate experience not only as what transforms boys into men, but also what makes them A'uwẽ. It is counted among the most valued features of men's culture, which is frequently differentiated from A'uwẽ women's culture. Thus, it not only makes men from boys, but more specifically, A'uwẽ men from A'uwẽ boys. In this manner, both youths and elders agree that the pre-initiate experience continues in the same format since time immemorial, serving for them as a strong symbol of historical continuity and a counterbalance to perceptions that contemporary life is associated with the disintegration of traditional values and diminishment of social well-being in A'uwẽ society.

\section{Novitiate adulthood (ritei'wa or dahi'wa)}

There exists a consensus in the literature that the formal age grade immediately following pre-initiation is young or novitiate adulthood, indicated by the term ritei'wa (Graham 1995; Lopes da Silva 1986; Maybury-Lewis 1967; Müller 1976). Although my research confirms this usage, I found evidence that a different term (dahi'wa) is considered more universally applicable for people at this stage of the life cycle. The term ritei'wa signifies those individuals in the dahi'wa age grade who compete in log races. Both terms are equally applicable to female and male members of this age grade. However, differently from men, women tend to be called dahi'wa rather than ritei'wa because not all women run log races. This finding refutes previous scholarship that asserted only males pertained to the ritei' $w a$ age grade (Lopes da Silva 1986; Maybury-Lewis 1967).

My data show that females pertain to the formal novitiate adult age grade (dahi'wa or ritei'wa) according to the same criteria as males and irrespective of their simultaneous status as members of other informal female age grades. This finding is significant because it differs from Lopes da Silva's reformulation of Maybury-Lewis's model, whereby the female and male life cycles are entirely distinct based on contrastive underlying logics (Lopes da Silva 1986). My findings suggest that these formal age grades are terminologically identical for males and females, with the exception that females do not pertain to pre-initiation because they do not spend time in seclusion in the pre-initiate house. Interestingly, these ideas have never been fully developed in the literature despite prominent female anthropologists having published important works on A'uwẽ social organization (Graham 1995; Lopes da Silva 1983).

For young men, becoming a novitiate adult is accompanied by the end of coresidence with their pre-initiate age-set peers and a return to their natal households. Returning to one's parents' home of after years of pre-initiate coresidence not only demands major behavioral changes of novitiate adults, but also casts them in new social positions relative to the rest of the adult community. As pre-initiates, they were both the youngest members of the formal age hierarchy and very much a focal point of community attentions. The daily, seasonal, annual, and quinquennial rhythms of the entire village revolved substantially around the pre-initiate house and its occupants. New novitiate men, in contrast, were comparatively marginal, being relegated to what is arguably a more socially isolating stage of the male life cycle than the symbolic seclusion of pre-initiation. They are excluded from the pre-initiate house, not yet involved in marriage and parenthood (this happens for many young men during their final years as novitiate adults), and still largely external to village political affairs.

Invisibility and home seclusion are important values for novitiate men, as they are discouraged from walking openly in the village and from visiting other houses. However, with 
few explicit social responsibilities, they are afforded ample liberty to pursue personal interests, provided they do not draw too much attention to themselves. Given this new freedom, they become particularly vulnerable to traditionalist accusations of being lazy, making mischief, and lacking work values. Interestingly, novitiate men often agree with such characterizations. Thus, whereas the pre-initiation age grade is explicitly emblematic of historical continuity through its involvement in the quintessentially traditional coresident educational process, novitiate manhood largely symbolizes its converse, historical change.

During their years as novitiate adults, male age-set peers remain extremely cohesive despite living apart. They continue meeting regularly to go on excursions into the forest, sing, play sports, and socialize together. They remain one other's primary peers and comrades. Nevertheless, being dislodged from the pre-initiate house and dispersed into natal households fragments the group and leads them gradually to turn their attentions elsewhere. As other scholars have suggested, this shift does represent a relative decline in age set cohesion (Graham 1995; Maybury-Lewis 1967). It also represents the beginning of their inclusion in other collectivities that will become more important later in life. While at home, a novitiate adult man may become more aware of what it means to share in his father's secrets. He may become an active listener in his father's political affairs and come to recognize the importance of lending his father political support.

Perhaps one of the most important aspects of being a novitiate adult male, both from their own perspectives and from those of members of other age grades, is they are considered sexually mature. After several years of novitiate adulthood, a young man's prospective wife may also become developmentally marriageable as indicated by the initial growth of her breasts. Thus, the criteria for marriageability differ for males and females. A prospective wife's parents will signal their interest in initiating the first active phase of marriage by delivering a corn bread loaf to the young man's parents at night. If they accept the loaf, the accord is sealed. From that point forward the two are considered boyfriend or fiancé (pi'õsĩwe) and girlfriend or fiancée (dasiwẽ). At that time, the young man begins visiting his fiancée by night. Graham $(1995,66-$ 74) provided a detailed account of one such young man's nighttime visits to the household she lived in. For the A'uwẽ, nighttime visits are thought of like dating in that they allow the couple to get to know each other for the first time and gradually facilitate his incorporation into her household.

Even after marriage, novitiate adult men continue to live in their natal households and visit their wives only at night. This behavior conforms to the social expectation that male members of their age grade remain out of sight in the village and not be seen visiting other people's households. Even though it is common knowledge that they visit their wives at night, they should not be seen doing it. In this context, secrecy is fictitious but nevertheless expected as an expression of respect and deference. Under the cover of dark, they take back routes around the village and quietly sneak in the front door. Sometimes the expectation of invisibility while visiting at night can create rather comical logistical problems, as in the case of one novitiate man who slept in too late to return to his own house unseen and was required to hide inside his fiancé's house all day long, unable to relieve himself.

Although novitiate men may suffer from a reputation as nontraditional, they nevertheless had a keen ability to uphold traditionalist A'uwẽ cultural values in a rapidly changing world. Although most novitiate adult men were still relatively free of social responsibilities, having 
graduated from the pre-initiate house but not yet married, this did not result in disregard for age set responsibility. Some novitiate men left the village temporarily to study, but most routinely passed their time hidden inside their natal households, out of sight from the rest of the village, as is expected of men of their age. When they were not home, they could usually be found attending school, playing soccer, or wiling away the hours in small groups out of sight. At night, they were often hidden lying under blankets in the middle of the soccer field listening to A'uwẽ music on a portable stereo.

Although those few locations comprised nearly the entire social orbit of novitiate men, they also diligently prepared for and participated in all ceremonial events, accompanied collective hunts, and responded to elders' calls for them to perform services for the community, such as clearing brush from the road or bagging the community rice harvest. Also, one of the traditionalist trademarks of novitiate manhood is holding their own separate evening men's council (warã), located to one side of the centrally located mature men's council (Figure 3), in conjunction with performing a round of singing in the village patio followed by a round in front of the houses (mãrãwi danho're). Through my participation in these activities, I came to appreciate how these young men strove to maintain this tradition. As novitiate adult men, they also maintain the collective age set spirit through secret song rehearsals (Figure 4), collective excursions into the forest, and a host of other group engagements that punctuate their usual pattern of wiling away the hours and days at home. Yet, with time, their attentions turn towards their future spouses and in-laws in anticipation of the next major shift in their social lives.

\section{Mature adulthood (iprédu)}

The next shift is passage to the mature adult (iprédu) formal age grade. According to some scholars, an additional age grade (ipredúpte, new mature adult, or danhohui'wa, mentor) occupies an intermediate position between novitiate and mature adulthood (Graham 1995; Lopes da Silva 1986; Müller 1976). I did not find the term ipredúpte in use during my fieldwork. Also, my interlocutors affirmed that the term danhohui'wa indicates mentorship but is not distinct from mature adulthood.

Passage from novitiate to mature adulthood does not occur simultaneously with the preinitiate initiation rites (danhono). Rather, it happens through distinct rites (dasi'tó) held separately for women and men during the months after pre-initiates conclude their initiation into novitiate adulthood. Thus, recruitment into the mature adult age grade occurs collectively for all same-sex members of an age set. Mature adulthood is a formal age grade occupied by multiple coed age sets from the time of their rite of passage from novitiate adulthood until death, and thus comprises the entire span of mature adulthood, including elder status for both women and men. In contrast, the distinction between the mature adult and elder (îhi) age grades cannot be considered discrete and sequential, as other authors have proposed. My research shows that all men who participate in morning and evening men's councils are called mature adults and that some of these individuals may also be called elders. Thus, elder status is an informal age grade indicating relative seniority or individual maturity of both women and men, with no direct correspondence with formal mature adulthood.

For men, mature adulthood differs from earlier stages in the life cycle in many respects, but there are perhaps three aspects that most transform the experience of its newest members. The first involves a strong pattern of uxorilocal post-marital residence, whereby many young 
mature men take up residence in their wives' households. The second is their inclusion in the dawn and dusk men's council meetings. The third is the association between becoming a mature adult and assuming the role of mentor to a newly inaugurated age set. Those three correlates of mature adult status bring about wholesale changes in young men's social positions relative to the rest of society. The first makes them junior in-laws and, potentially, future heads of household in new residential hierarchies. The second sets them at the periphery of a political arena in which they will eventually become senior members. The third puts them solidly in charge of the welfare of their pre-initiate protégés, a responsibility that continues throughout life, even after their protégés leave the pre-initiate house. Thus, achieving mature adult status in the formal age grade system positions them as seniors relative to much of society but also relegates them to junior status within new domestic settings and the political arena. It also gives them new opportunities to deepen and widen their social networks and thereby gradually transition out of the subordinate roles that have hitherto characterized their social position in the community.

Adjusting to life in one's wife's household can be difficult, even disagreeable, at first (later they may become more relaxed). Graham (1995) discussed just how socially restrictive the early stages of marriage can be for a young husband, when he and his wife's family do not yet know each other well and are first faced with reconciling their potentially disparate political allegiances. In deference to this potential for conflict and to his subordinate position in his new household, bride service protocol demands that he avoid calling attention to himself and never look directly at or speak directly to his parents-in-law. Furthermore, I observed that fathers-inlaw may place high expectations on their new sons-in-law to help provision the household through subsistence activities such as hunting, fishing and working in his father-in-law's garden, as well as seeking paid work (cf. Maybury-Lewis 1967). At this early phase of mature adulthood, a man's status as son-in-law defines a new relationship of social subordination that he now adds to some of the other subordination relationships that have thus far characterized his life, such as being protégé to his age-set mentors and being son and grandson to his patrifilial relatives. Only gradually do those junior statuses give way to senior statuses as mentors, fathers, and heads of household. These shifting roles are part of A'uwẽ concepts regarding proper age-related relations and good social living.

Marriage usually subjects a young man to the subordinate role of son-in-law in his wife's household, but it also can make him a father and thereby provide him with the opportunity to establish his own domain of intimacy and influence within his father-in-law's home. Assuming a young mature man continues to live in his father-in-law's household, for some time he remains subordinate within the household. Eventually, however, he may assume dominance through his father-in-law's death. This pattern of generational alternation between dominant patrifilial associations within households has been described as a defining feature of home life with important ramifications in the political sphere (Maybury-Lewis 1967).

By the time a mature man becomes head of household, he has largely shed the subordinate roles of his youth. Even if his father and father-in-law are still living, he is now considered an independent adult with his own realm of primary responsibilities, for which he was previously prepared by his secular age set mentors. Although he maintains an especially intimate relationship with his living age-set mentors, only in limited circumstances do they oversee his activities. With this new degree of social autonomy, a mature man is faced with a 
reversal of roles that both extends and potentially politicizes his domestic domain. His adult sons may move out to live with their new wives and his new sons-in-law may move in, creating the possibility of a generational gap in domestic male political fidelity. Despite the potential for conflict these arrangements introduce, they also carry the opportunity for sons-in-law and fathers-in-law to earn each other's devotion and unite their interests, thereby deepening their mutual spheres of influence at home and throughout the village. That process links the domestic and political spheres.

The transition mature men undergo from subordinate sons-in-law to dominant fathersin-law is paralleled by a process whereby they gradually pass from relative political silence to assuming voices of leadership in the community. The primary public political forum is the men's council usually held every dawn and evening (Graham 1995). It is at the mature men's council that I observed topics of interest to the entire community being discussed, deliberated, and decided. Being a mature man is synonymous with permission to participate in this council meeting, but the nature of that participation changes substantially over the course of one's tenure.

Men's council meetings are highly conventionalized in ways that favor seniority and influence within an egalitarian morality of consensus. Twice each day, men carrying benches and chairs (formerly mats) approach the center of the village patio in ones and twos from their respective houses. They usually sit in the same places at every meeting, sitting or lying on their backs in an irregular open circle that seems to recapitulate the village itself. Graham (1995) described the seating arrangement as deriving from the progressive and fixed placement of new members between opposite exogamous moiety members of the next senior age set. Although some elder men choose to sit next to their opposite-moiety formal friends ( ('amo), my consultants say they do not currently follow any formal seating order.

During meetings, men sit at different distances from the focal point of circle, where during chilly dry-season meetings an open fire often burns. Vocal elders occupy an inner tier closest to the center and comparatively muted younger men cluster in several small groups at the periphery, most often with members of their own age set and their adult mentors or protégés. Intermediately aged men tend to disperse themselves between the center and the periphery. That spatial pattern mirrors leadership organization within the council. This arrangement derives from an explicit expectation that younger men should remain silent at the periphery out of respect for their elders. Rather, they should listen during meetings and thereby learn over a period of many years how to respectfully speak their opinions.

The role new mature adults assume as mentors to pre-initiate protégés occurs at different times depending on then the first penis sheath group is inducted to the pre-initiate house, often about a year after the mentors' age set is initiated into mature adulthood. This experience is a test of responsibility and endurance for the mentors, as well as an opportunity to show dedication and compassion for their protégés. Mentoring requires that mentors demonstrate and stimulate the good behavior expected of pre-initiates, which can entail everything from accompanying them during grueling ceremonies to rounding them up to clean a dusty and disheveled preinitiate house. Never are mentors bossy, antagonistic, or demeaning. Their role is to encourage good behavior through intimacy and support. This aspect of mature adulthood is centered in the pre-initiate house and requires that married and unmarried mentors schedule their time to ensure the pre-initiates are well attended to. Mentoring pre-initiates requires constant (day and night) 
coordinated oversight and companionship. A greater portion of the day-to-day responsibility falls on unmarried mentors, who have more time on the hands and less competing responsibilities. But all mentors participate and attend important events, such as ceremonial presentations. New mature adults are never alone in this effort, as they continue to be benevolently watched over and encouraged by their mentors, their mentors' mentors, and so on. This chain of mentorship is what transforms the pre-initiate experience into a social institution that transcends all generations and unites age sets connected through intimate bonds with a sense of common purpose, interest, and camaraderie.

\section{Mentorship and camaraderie}

For men and women, lifelong named secular age sets ( $\left.d a^{\prime} u s u^{\prime} z a^{\prime} r a\right)$ are the most specific form of age ranking for the greater part of the life cycle. In many respects, they are also the most socially salient, by which I mean that they are the most talked about in daily social life, and condition how people relate to one another in a highly conscious and nuanced manner. In my field experience, these age sets were how people usually reckoned age in everyday circumstances, much as they were when Maybury-Lewis (1967) conducted research in the same community in the 1950s. Everyone in society belongs to an age set, with the exception of a few individuals with severe developmental disabilities. Membership in a particular age set places each person in explicit age juxtaposition to the rest of society and operates in conjunction with other aspects of social identity, such as informal age status, gender, and kinship, as a basis for how people relate to one another socially.

A'uwẽ secular age sets are not only delineated in terms of sequence, but they are named in a highly specific manner. A fixed repetitive sequence of eight names is applied to successive age sets (Table 1). The cycle repeats every eight age sets, with the newest age set adopting the name that was last used eight age sets previously. Despite that strict pattern, age set names are not what give age sets personal and interpersonal meaning. Rather, they take on meaning through lived experience. This is most obviously so for males, whose first direct experience of belonging to an age set comes about during an extended seclusion in the pre-initiate house. This formative experience socially orients boys relative to members of their own age sets, to members of other age sets, and to adult sociality itself.

Living in the pre-initiate house can initially be a difficult experience, marked by feelings of missing one's family. Yet, despite any initial challenges in adjusting to life in the pre-initiate house, the boys soon become enfolded in a sense of age set camaraderie with lifelong implications. One of the most striking aspects of the pre-initiate coresident experience, as I came to know it, was the special relationship of companionship and sponsorship that developed between pre-initiates and their mentors. This relationship is especially strong between individual mentors (danimiwanho) and their specific protégés, who accompany one another during daily activities and enjoy a unique sense of mutual solidarity and allegiance. Thus, pre-initiate coresidence is a fraternal social milieu not only between age set peers, but also between them and their mentors.

Because the close relationship between mentors and their protégés continues after residence in the pre-initiate house, every second group of pre-initiate coresidents joins a lifelong chain of mentors and protégés connected through intimate bonds of friendship and respect. All members of such a mentorship chain share a morality of loyalty irrespective of their relative 
ages. They are all on the same side and designate each other "our age set side" or "people on our age set side" (waza'runiwimhã). They also commonly call each other by a series of terms that generically indicate same-sidedness (us, as opposed to them), and may be used for members of one's age set side, or any number of other associations. Examples are "our side" (waniwĩmhã) and "people on our side" (wahöibaniwimhã), terms that do not make specific reference to age set sidedness.

Although Maybury-Lewis (1967) and Müller (1976) acknowledged the same-side/otherside opposition created through alternating bonds between pre-initiate protégés and their mentors, they did not communicate how central it is to the male A'uwẽ experience. MayburyLewis later came to characterize that opposition as a moiety system, although he did not develop the idea extensively (Maybury-Lewis 1979). In my experience, members of all same-side age sets share a deep sense of identity, an interest in one another's affairs, and a presumption of secrecy in certain domains. In certain contexts, any member of this chain may lend a hand to the pre-initiate coresidents to ensure their success and by extension, the success and good reputation of their age set side.

If the members of this chain of every second age set consider themselves to be on the same side, who do they consider to be on the other side? The other side, their rivals and disconfidants, consists of the alternate chain of age sets, also spanning the range from youth to elders, but offset by one step. Members of the first side call these rivals "the other age set side" or "people on the other age set side" (hö'amoniwimhã). They may also call those people by a series of terms that indicate other sidedness in a generic sense, such as "their side" (onniwĩmhã) and "people on their side" (õhöhöibaniwimhna). In other words, adjacent age sets belong to opposite "sides" or agamous moieties and alternate age sets belong to the same "side" or agamous moiety. Each side forms a unified group of mutual interest and concern, keeping one another's secrets from members of the other moiety. Members of one's side share a sense of identity and mutuality derived above all from the intimate social bonds formed in the pre-initiate house, both as protégés and, later, as mentors to the next set of protégés. Thus, I would qualify Lopes da Silva's $(1986,206)$ characterization of mentors as "the executors of concern for society-at-large." As a group, mentors are aligned with one side and one side only, making them the executors of concern for half of society.

In most day-to-day interaction, members of adjacent age sets, and by extension, members of opposite age set moieties, enjoy provoking each other in lighthearted but demeaning ways, attributing to them such qualities as cowardice, weakness, powerlessness, slowness, and clumsiness (Lopes da Silva 1986). Popular age set pranks designed to teach younger individuals in the other age set moiety to mind their own business involves rubbing white-lipped peccary (Tayassu pecari) urine on the victim's legs or making him smell dried peccary feces. In addition to being grotesque and effective tools for public humiliation, each is believed to promote valued skills in the victim. Peccary urine applied to the legs is thought to make one a tireless runner while smelling peccary feces is believed to improve one's ability to detect their scent, which is useful for hunting. Thus, in more ways than one, such age set jokes are intended to leverage the adversarial social relationship of moiety opposition for the sake of stimulating the good and appropriate development of youth.

These configurations of fraternity and rivalry between age sets grouped into age set moieties comprise a morality of camaraderie and competition, which contributes to a social 
fabric of how people are thought to properly relate. On the one hand, groups of mentors and protégés teach and protect one another while, on the other hand, members of opposite-moiety age sets watch vigil over one another and encourage good behavior through antagonistic feedback. Both cases are imbued with cultural understandings of betterment - encouraging good and proper behavior by one's juniors, behavior that society judges as constructive for individuals and for society at large. They are contrastive logics of respectful relations, both understood to stimulate the transformation of boys into responsible adults. This dynamic within and between age set moieties is the crux of the moral equivalence to war for A'uwẽ manhood - it serves to bond all of male society to a common purpose for the benefit of society at large.

As an emotive experience, age set camaraderie is the milieu through which individualized youth come together in friendship and commitment to represent themselves to society as culturally and socially obedient, meek, strong, and beautiful. It is through their dedication to one another that they gain so much pleasure from hiding internal aspects of age set camaraderie from outsiders, such as other age set moiety members and women. This dynamic creates a scenario of difference that places high moral value on certain kinds of lies, trickery, and deceit for the good image of the group.

Contrary to my own cultural expectations that mentoring relationships would be more about proctorship and tutelage, I found the relationship between mentors and their protégés to be much more about intimate comradeship, sponsorship, and permissiveness, what Lopes da Silva characterizes as kind of formal friendship (Lopes da Silva 1986), albeit an unequal one. Often, individual mentors will accompany their specific protégés to the river to take a bath and instruct them on how to prepare their bodies to become strong. They share with them secret ethnobotanical knowledge about plants that make one run fast in inter-age set competitions. Such gestures imply mutual solidarity and allegiance between mentors and protégés.

The close bonds between mentors and protégés continue long after the boys leave the pre-initiate house. For example, mentors continue to guide their protégés during ceremonial and song rehearsals. Usually also present were a few mentors' mentors and mentors' mentors' mentors and so on. This sort of participatory oversight by members of multiple same-side age sets was typical of ritual contexts and not uncommon in some casual contexts, such as hunting or fishing. It illustrates that the special relationship between mentors and protégés transcends the pre-initiate house experience, continuing throughout life and leading to a sense of unity among members of a continuous series alternate age sets and a morality of adversity relative to the opposite age set moiety. Together they comprise the masculine universe and work towards the common end of creating good and responsible men from boys.

\section{Irreproachable social arrangements}

Although elders routinely affirm the inherent correctness of rites of passage, the protégé/mentor relationship, and the coresident experience in the pre-initiate house for the proper transformation of A'uwẽ boys into A'uwẽ men, the same individuals are just as likely to disparage these as weakened in comparison to the past. Some have gone so far as to tell me they believe there is nothing left, that they are already irreparably misconfigured. I came to reconcile this apparent contradiction in their discourse by understanding that mentorship and pre-initiate coresidence are viewed as irreproachable social arrangements rooted in "our traditions; our culture" (wahöimanazé) but to the extent the pre-initiate house is a collection of fallible young 
individuals (e.g., pre-initiates and mentors), it is a constant reminder of the inevitability and undesirability of change.

From my point of view as an outsider, I perceive continuity in the protégé/mentor relationship, affirmation that there is truth in elders characterizations of it as similar to ancestral times and integral to the construction of their resilient identity as A'uwẽ Uptabi (The True People) despite the magnitude of social, economic, and environmental change that has occurred over the last half-century. I have participated in lengthy ceremonial activities during which the mentors seemingly surpassed their physical limits to provide "reinforcement" for their protégés. I have passed entire nights hidden in the forest assisting our protégés with their song rehearsals, accompanied by several of our mentors and several of theirs. I have accompanied age set fishing expeditions during which adult protégés provide sustenance for their mentors. Some content of interaction may have changed (hunting is less popular) but the age set activities I observed remain popular for boys and men of all ages. Additionally, the morality of the relationship and its vigorous presence throughout life were apparent to me, as it was to elders. In this sense, mentorship and camaraderie, and rites of passage they entail, continue to serve as a moral equivalent to war, providing an avenue for the promotion of male unity of purpose and duty to society throughout contemporary life. My recognition of these examples of cultural continuity is not for the sake of nostalgia, but to identify how some traditionalist activities serve as anchors in the construction of social and ethnic identity.

The movement to protect Indigenous knowledge provides the insight that what makes knowledge traditional is not its antiquity, but rather the culturally specific social process of sharing and learning it (Battiste and Henderson 2000). This point applies equally well to the social identity processes discussed here. A'uwẽ elders seem to share this point of view regarding manhood, mentorship, and camaraderie, and by extension the construction of A'uwẽ ethnic identity among young males. I would elaborate on this point by reemphasizing that a man's commitment to his protégés, his own mentors, and his age set moiety is mirrored by his dedication to watching vigil over younger members of the opposite age set moiety and fulfilling one's duties as a husband, son-in-law, and father within an extended family. The former imply the latter. Taken together, manhood involves service to all of society, not just one's own protégé and mentor. A'uwẽ social production of manhood functions as a moral equivalent of war in that it identifies people with their civic polity and commits them to the good of their society. Even antagonistic opposite age set moiety relations are rooted in benevolent desires to promote the proper social production of A'uwẽ men.

This is not to say the A'uwẽ are free of conflict and political dissent. To the contrary, political factionalism is one of their most famous anthropological features (Maybury-Lewis 1967). Yet, the mentorship relationship and sense of camaraderie derived through the pre-initiate house experience are not the source of the problem and may help mitigate against it. When I participated in a spiritual rite of initiation (darini) over the course of several weeks in 2018, one of my secular age set mates who had moved to a new village in 2006 due to political conflicts returned to dance with us and thereby reinforce our endurance. I believe it was the first time he had returned in 12 years, but he was received as a comrade as though he had never left. The bond that united our age set was, in that moment, stronger than the smoldering conflict between the villages. 
It has been argued that age set systems provide social integration in warring societies with extreme seasonal demographic fluctuations (Ritter 1980). This proposal fits the A'uwẽ case historically and is ethnographically plausible given that age sets provide a safe social place for individuals visiting or traveling with people from unfamiliar villages. If true, this explanation gives insight into why the A'uwẽ process of producing manhood emphasizes trials and suffering that seem to resemble militaristic training and reinforces its contemporary role as a moral equivalent of war. In any event, it is a process that meets the criterion of social constriction that promotes a sense of common purpose, fraternity, and dedication to community.

William James did not propose the moral equivalent of war to eliminate all political division and create an ideologically uniform society. Rather, he was looking for something besides war with the capacity to rally people towards a common purpose and to consider the best interest of the citizenry. As I write this paper, this goal seems like wishful thinking considering the extreme political and social division afflicting both the United States and Brazil. However, the A'uwẽ case demonstrates that such a mechanism is possible for a localized community given a sociocultural framework providing the means to reproduce camaraderie within and between cohorts of youth and young adults. For A'uwẽ men, the ethnic identity entailed by manhood is socially constructed in the pre-initiate house and regenerated through the camaraderie that binds multigenerational chains of mentors and protégés with a morality of trust and unified commitment to the betterment of all youth.

These findings suggest a need to revise or complement certain theoretical orientations regarding the construction of social and ethnic identity in Amazonia and elsewhere. Much of recent literature on social identity in Amazonia emphasizes an interdependent contrast between "convivial consanguinity" and "predatory affinity" to the exclusion of other kinds of non-kin social relations, including friendship (Santos-Granero 2007, 1; Viveiros de Castro 2002). The A'uwẽ example demonstrates the relevance of highly formal and privileged configurations of camaraderie between protégés, mentors, and members of an age set moiety that transcend common friendship and do not pertain to the consanguine:affine equation. They comprise an additional key dimension of social identity that does not fit into previously emphasized orders of social relations for this geographical region. Ethnography of Amazonia should expand its reach to consider the contributions of age organization and ritualized camaraderie to the construction of social and ethnic identity.

Recent and classic literature on the social construction of ethnic identity often emphasizes difference, conflict, and even violence as features of the boundaries between groups that promote identity formation (Barth 1969; Fearon and Laitin 2000; Thurairajah 2020). In contrast, some recent scholarship deemphasizes the role of crossing delineated boundaries between ethnic groups as mechanisms for identity construction (Eriksen 2018). Regarding the A'uwẽ specifically, Graham (2005) discusses public cultural productions as enterprises seeking existential recognition without making use of external points of ethnic reference. I have provided ethnographic evidence of a different order of social relations contributing to ethnic identity and commitment to civic membership that do not involve difference between ethnic groups, societies, or nationalities. In the case of A'uwẽ mentorship and manhood, there is a sense of conflict intrinsic to the dynamic, but it is located between equals - age sets of cyclical identity and age set moieties of morphological complementarity. It is not necessary for the construction of A'uwẽ masculine identity that they draw contrasts between themselves and other ethnic 
groups, although they may do so in other contexts. Their references for identity and exclusion are both located within society ("our age set side" and "the other age set side"), thus creating an internal mechanism by which male youth - both pre-initiates and mentors - may begin the process of constructing uniquely A'uwẽ social and ethnic identities.

\section{Acknowledgements}

I thank the residents of Pimentel Barbosa, Etênhiritipá, and Novo Paraíso villages for generously opening their lives and homes to me during my many visits to their communities and for participating in my study of their society. I especially thank members of my secular age set (êtẽpá) and our mentors (hötörã) for their friendship and confidence throughout my tenure as their peer and protégé, respectively. This article benefitted from careful review of previous versions by William Balée, Ricardo V. Santos, and Carlos Coimbra Jr., although all mistakes are my own. The study was financed at various times by the Fulbright Commission (DDRAF no. P022A040016), the Tulane Graduate Fund, and the Conselho Nacional de Desenvolvimento Científico e Tecnológico (CNPq 500288/2009-7, 500072/2010-8, 475750/2012-8, 306099/2016-0, 307773/2019-1). Research permissions were granted by the Tulane Institutional Review Board, the Brazilian National Research Ethics Commission, the Brazilian National Indian Foundation, and A'uwẽ community councils.

\section{References cited}

Armstrong, Jeremy. 2013. "'Bands of Brothers': Warfare and Fraternity in Early Rome." Journal of Ancient History 1 (1): 53-69. https://doi.org/10.1515/jah-2013-0004.

Barth, Fredrik. 1969. "Introduction." In Ethnic Groups and Boundaries, edited by Fredrik Barth, 9-38. Boston: Little, Brown, and Co.

Battiste, Marie, and James Youngblood (Sa'ke'j) Henderson. 2000. Protecting Indigenous Knowledge and Heritage: A Global Challenge. Saskatoon, Canada: Purich Publishing.

Bernardi, Bernardo. 1985. Age Class Systems: Social Institutions and Politics Based on Age. Cambridge: Cambridge University Press.

Brookins, Craig C. 1996. "Promoting Ethnic Identity Development in African American Youth: The Role of Rites of Passage." Journal of Black Psychology 22 (3): 388-417. https://doi.org/10.1177/00957984960223008.

Burk, James. 1999. "Military Culture." In Encyclopedia of Violence, Peace, and Conflict, Volume 1, edited by Lester R. Kurtz and Jennifer Turpin, 447-62. San Diego: Academic Press.

Chrisman, Noel J. 1974. "Middle Class Communitas: The Fraternal Order of Badgers." Ethos 2 (4): 356-76.

Coimbra Jr, Carlos E. A., Nancy M. Flowers, Francisco M. Salzano, and Ricardo Ventura Santos. 2002. The Xavánte in Transition: Health, Ecology, and Bioanthropology in Central Brazil. Ann Arbor: University of Michigan Press.

Dent, Rosanna. 2020. "Subject 01: Exemplary Indigenous Masculinity in Cold War Genetics." The British Journal for the History of Science First view: 1-22. https://doi.org/10.1017/S000708742000031X.

Durkheim, Émile. 1915. The Elementary Forms of the Religious Life, a Study in Religious Sociology. London: G. Allen \& Unwin. 
Erickson, Kirstin C. 2008. Yaqui Homeland and Homeplace: The Everyday Production of Ethnic Identity. Tucson: University of Arizona Press.

Eriksen, Thomas Hylland. 2018. "Beyond a Boundary: Flows and Mixing in the Creole World." In Ethnic Groups and Boundaries Today: A Legacy of Fifty Years, edited by Thomas Hylland Eriksen and Marek Jakoubek, 133-51. London: Routledge.

Fausto, Carlos. 2002. "Banquete de Gente: Comensalidade e Canibalismo Na Amazônia." Mana 8 (2): 7-44.

Fearon, James D., and David D. Laitin. 2000. "Violence and the Social Construction of Ethnic Identity." Edited by Paul Brass, Francis M. Deng, Bruce Kapferer, John McGarry, Brendan O’Leary, Gérard Prunier, and Susan L. Woodward. International Organization 54 (4): 845-77.

Flowers, Nancy M. 1983. "Forager-Farmers: The Xavante Indians of Central Brazil." Ph.D. dissertation, New York: City University of New York.

Garfield, Seth. 2001. Indigenous Struggle at the Heart of Brazil: State Policy, Frontier Expansion, and the Xavante Indians, 1937-1988. Durham, NC: Duke University Press.

Giaccaria, Bartolomeu. 2000. Xavante Ano 2000: Reflexões Pedagógicas e Antropológicas. Campo Grande: Editora UCDB.

Giaccaria, Bartolomeu, and Adalberto Heide. 1984. Xavante: Auwẽ Uptabi, Povo Autêntico. São Paulo: Editora Salesiana Dom Bosco.

Giraldin, Odair. 2011. "Creating Affinity: Formal Friendship and Matrimonial Alliances among the Jê People and the Apinaje Case." Vibrant: Virtual Brazilian Anthropology 8 (2): 403-26. https://doi.org/10.1590/S1809-43412011000200018.

Graham, Laura R. 1995. Performing Dreams: Discourses of Immortality among the Xavante of Central Brazil. Austin: University of Texas Press.

Graham, Laura R. 2005. "Image and Instrumentality in a Xavante Politics of Existential Recognition: The Public Outreach Work of Eténhiritipa Pimentel Barbosa." American Ethnologist 32 (4): 622-41. https://doi.org/10.1525/ae.2005.32.4.622.

Gregor, Thomas A. 1979. "Secrets, Exclusion, and the Dramatization of Men's Roles." In Brazil: Anthropological Perspectives, edited by Maxine Margolis, 250-69. New York: Columbia University Press.

Gutmann, Matthew C. 1997. "Trafficking in Men: The Anthropology of Masculinity." Annual $\begin{array}{lllll}\text { Review of } & \text { Anthropology } & 26 & \text { (1): }\end{array}$ https://doi.org/10.1146/annurev.anthro.26.1.385.

Herzfeld, Michael. 1985. The Poetics of Manhood: Contest and Identity in a Cretan Mountain Village. Princeton, NJ: Princeton University Press.

Jackson, Jean E., and María Clemencia Ramírez. 2009. "Traditional, Transnational, and Cosmopolitan: The Colombian Yanacona Look to the Past and to the Future." American Ethnologist 36 (3): 521-44. https://doi.org/10.1111/j.1548-1425.2009.01177.x.

James, William. 1910. "Proposing the Moral Equivalent of War," 1910. https://www.laphamsquarterly.org/states-war/proposing-moral-equivalent-war.

Keesing, Roger M. 1982. "Introduction.” In Rituals of Manhood: Male Initiation in Papua New Guinea, by Gilbert H. Herdt, 1-43. Berkeley: University of California Press.

Little, Kenneth L. 1949. "The Role of the Secret Society in Cultural Specialization." American Anthropologist 51 (2): 199-212. 
Lopes da Silva, Aracy. 1983. "Xavante: Casa-Aldeia-Chão-Terra-Vida." In Habitações Indígenas, edited by Sylvia Caiuby Novaes, 33-56. São Paulo: Editora da Universidade de São Paulo.

Lopes da Silva, Aracy. 1986. Nomes e Amigos: Da Prática Xavante a Uma Reflexão Sobre Os Jê. São Paulo: Universidade de São Paulo.

Lumby, Bronwyn. 2010. "Cyber-Indigeneity: Urban Indigenous Identity on Facebook." The Australian Journal of Indigenous Education 39 (S1): 68-75. https://doi.org/10.1375/S1326011100001150.

Mauss, Marcel. 1966. The Gift; Forms and Functions of Exchange in Archaic Societies. London: Cohen \& West.

Maybury-Lewis, David. 1967. Akwẽ-Shavante Society. Oxford: Clarendon Press.

Maybury-Lewis, David. 1979. "Cultural Categories of the Central Gê." In Dialectical Societies:

The Ge and Bororo of Central Brazil, edited by David Maybury-Lewis, 218-48. Cambridge, MA: Harvard University Press.

McCallum, Cecilia. 2003. Gender and Sociality in Amazonia: How Real People Are Made. Oxford: Berg Publishers.

Merton, Robert K. 1957. Social Theory and Social Structure. Glencoe, IL: Free Press.

Müller, Regina A. P. 1976. "A Pintura Do Corpo e Os Ornamentos Xavante: Arte Visual e Comunicação Social.” Masters thesis, Campinas: Universidade Estadual de Campinas.

Overing, Joanna. 1989. "Styles of Manhood: An Amazonian Contrast in Tranquility and Violence.” In Societies at Peace: Anthropological Perspectives, edited by Signe Howell and Roy Willis, 79-99. London: Routledge.

Prins, Adriaan Hendrik Johan. 1953. East African Age-Class Systems. Groningen: J.B. Wolters. Ramos, Alcida Rita. 2012. "The Politics of Perspectivism.” Annual Review of Anthropology 41 (1): 481-94. https://doi.org/10.1146/annurev-anthro-092611-145950.

Ritter, Madeline Lattman. 1980. "The Conditions Favoring Age-Set Organization.” Journal of Anthropological Research 36 (1): 87-104.

Santos-Granero, Fernando. 2007. "Of Fear and Friendship: Amazonian Sociality beyond Kinship and Affinity." Journal of the Royal Anthropological Institute 13 (1): 1-18.

Seeger, Anthony, Roberto DaMatta, and Eduardo B. Viveiros de Castro. 2019. "The Construction of the Person in Indigenous Brazilian Societies." HAU: Journal of Ethnographic Theory 9 (3): 694-703. https://doi.org/10.1086/706805.

Senecal, Gary. 2017. "Solidarity and Camaraderie-A Psychosocial Examination of Contact Sport Athletes' Career Transitions.” Cogent Business \& Management 4 (1): 1280897. https://doi.org/10.1080/23311975.2017.1280897.

Simpson, Leanne R. 2004. "Anticolonial Strategies for the Recovery and Maintenance of Indigenous Knowledge." The American Indian Quarterly 28 (3): 373-84. https://doi.org/10.1353/aiq.2004.0107.

Stewart, Frank Henderson. 1977. Fundamentals of Age-Group Systems. New York: Academic Press.

Syrett, Nicholas L. 2009. The Company He Keeps: A History of White College Fraternities. Chapel Hill: University of North Carolina Press. 
Thurairajah, Kalyani. 2020. “'Who Are We without the War?': The Evolution of the Tamil Ethnic Identity in Post-Conflict Sri Lanka." Ethnicities 20 (3): 564-86. https://doi.org/10.1177/1468796819846960.

Van Gennep, Arnold. 1960. The Rites of Passage. Chicago: University of Chicago Press.

Viveiros de Castro, Eduardo. 1998. "Cosmological Deixis and Amerindian Perspectivism." Journal of the Royal Anthropological Institute 4: 469-88.

Viveiros de Castro, Eduardo. 2002. A Inconstância Da Alma Selvagem. São Paulo: Cosac \& Naify.

Weedon, Gavin. 2015. "Camaraderie Reincorporated: Tough Mudder and the Extended Distribution of the Social." Journal of Sport and Social Issues 39 (6): 431-54. https://doi.org/10.1177/0193723515570676.

Welch, James R. 2010. "Hierarchy, Symmetry, and the Xavante Spiritual Life Cycle." Horizontes Antropológicos 16 (34): 235-259. https://doi.org/10.1590/S010471832010000200011.

Welch, James R. 2015. "Learning to Hunt by Tending the Fire: Xavante Youth, Ethnoecology, and Ceremony in Central Brazil." Journal of Ethnobiology 35 (1): 183-208. https://doi.org/10.2993/0278-0771-35.1.183.

Welch, James R., Ricardo Ventura Santos, Nancy M. Flowers, and Carlos E. A. Coimbra Jr. 2013. Na Primeira Margem Do Rio: Território e Ecologia Do Povo Xavante de Wedezé. Rio de Janeiro: Museu do Índio/FUNAI. 


\section{Figures}

Figure 1 Male informal and formal secular age grade systems.

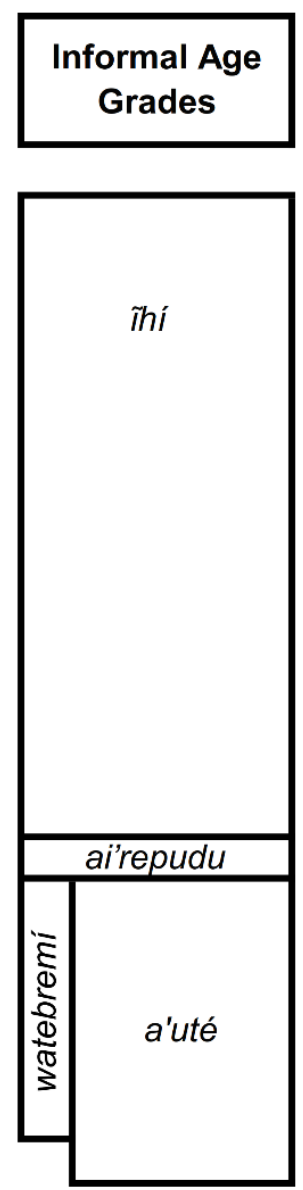

$$
\begin{aligned}
& \text { Formal Secular } \\
& \text { Age Grades }
\end{aligned}
$$

ritei'wa / dahi'wa

heroi'wa

wapté

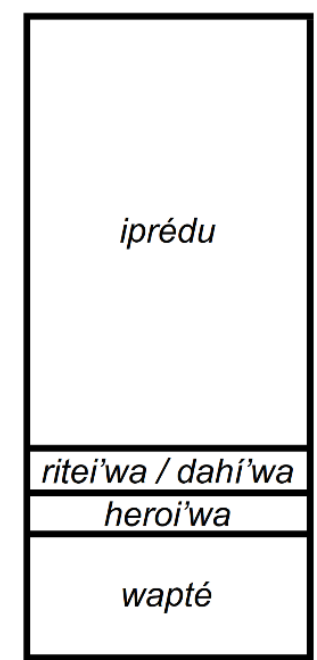


Figure 2 Ceremonial "water splashers" (watei'wa) during liminal phase before ear piercing and initiation into novitiate adulthood. Photo by James R. Welch, 2011.

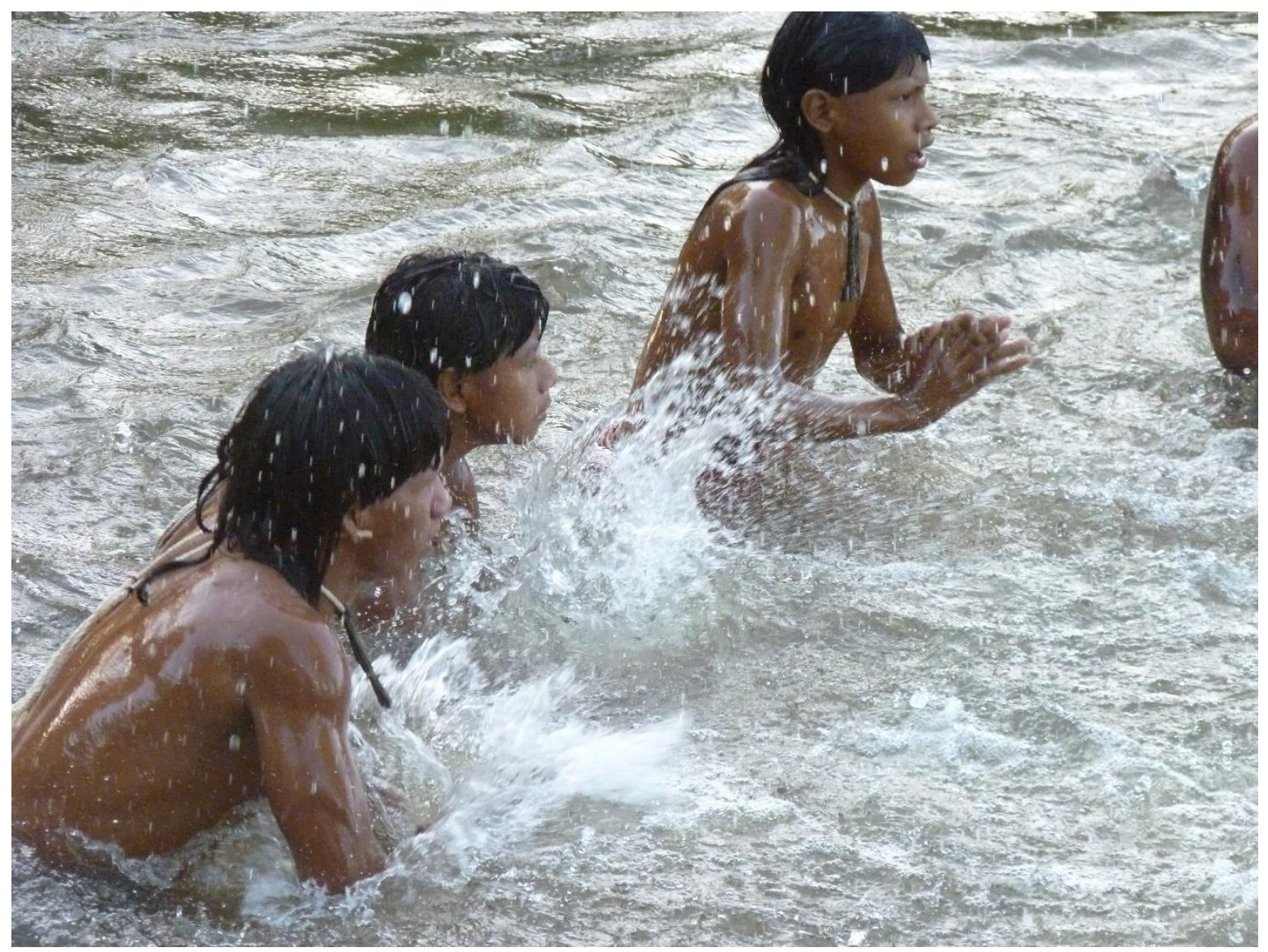


Figure 3 The author participating in novitiate men's evening men's council (warã), held to one side of the centrally located mature men's council. Photo by Carlos E. A. Coimbra Jr., 2005.

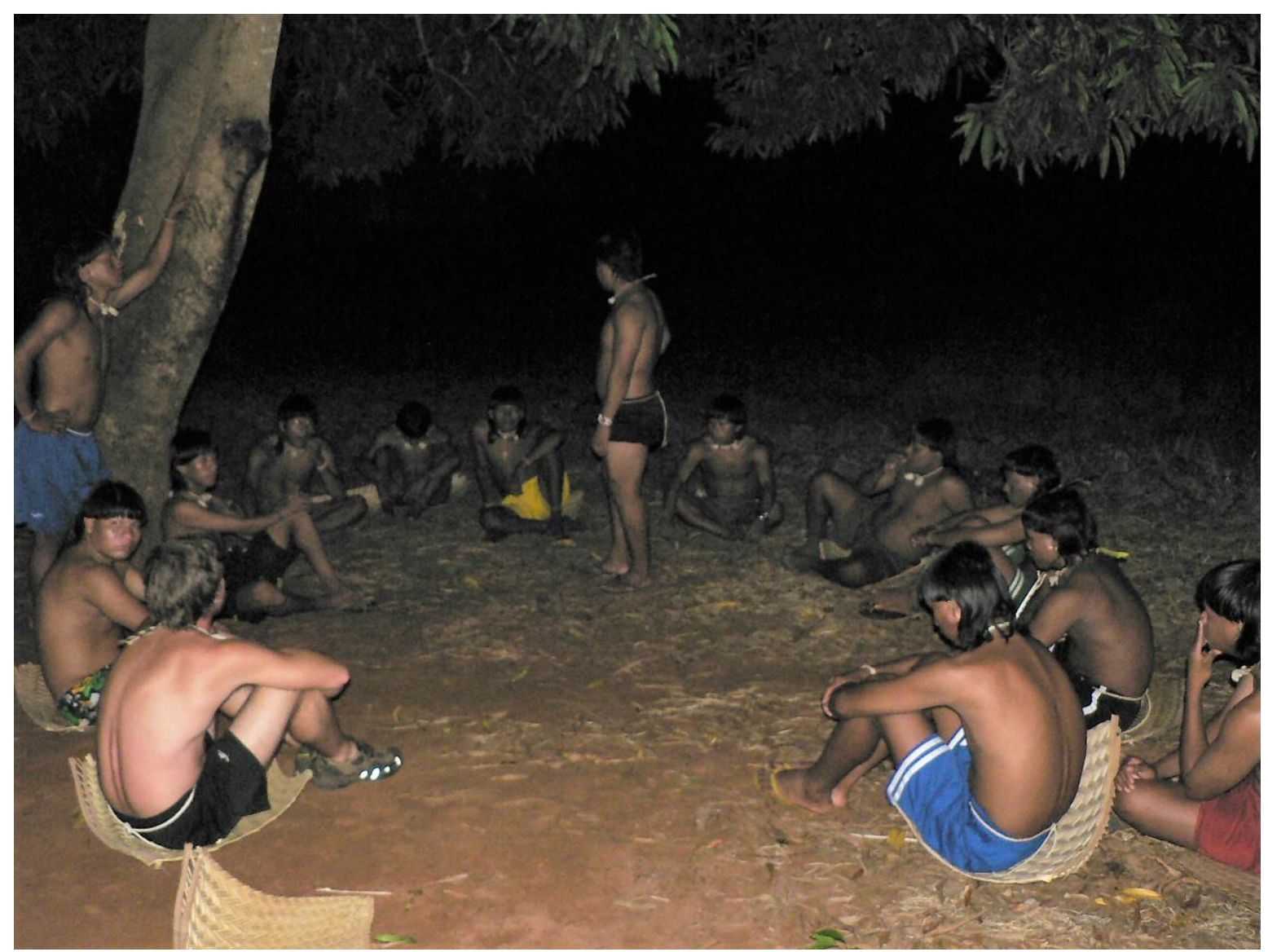


Figure 4 Novitiate adults rehearsing song repertoire at hidden location in the forest. Photo by James R. Welch, 2005.

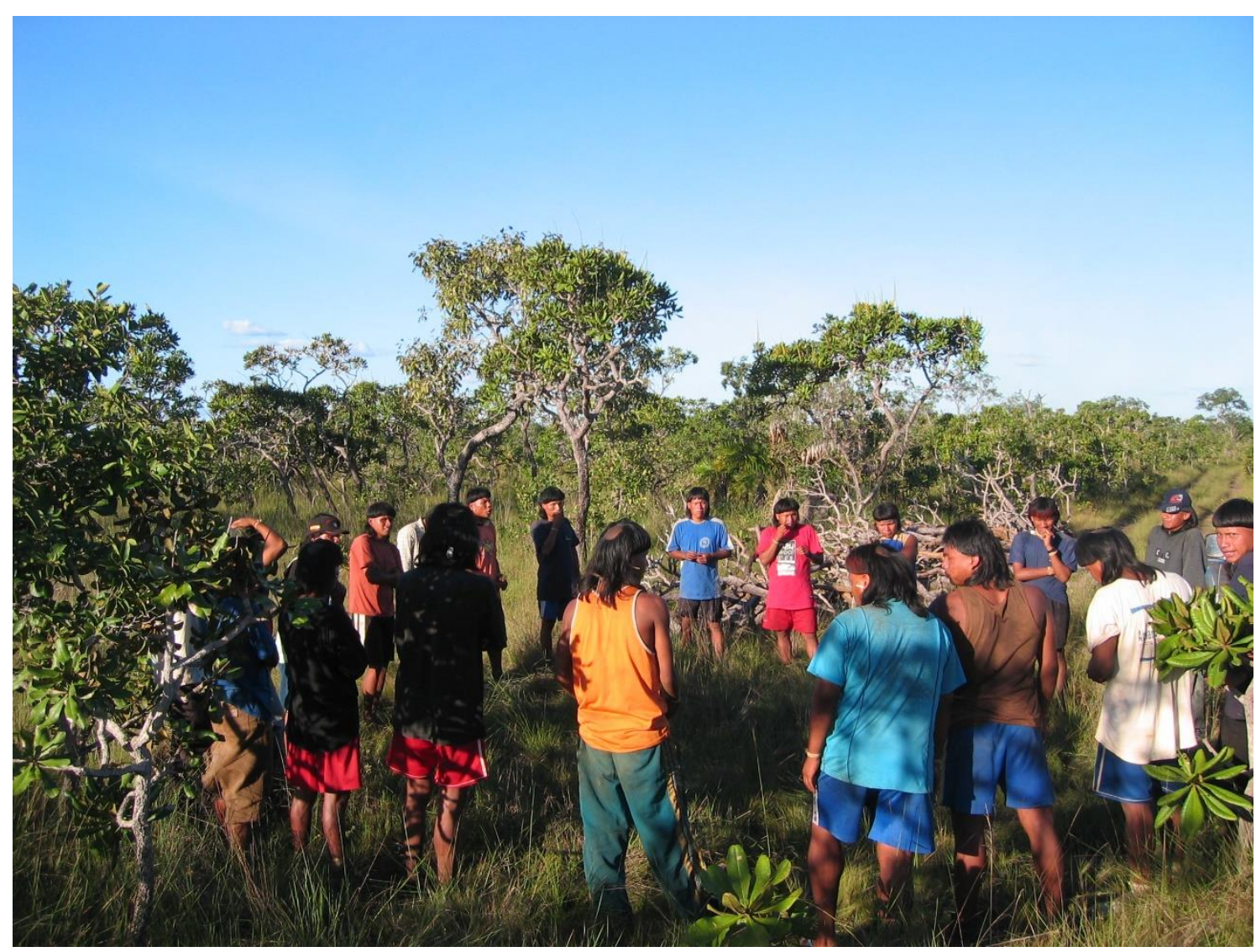




\section{Table}

Table 1 Age set names and associated terms.

\begin{tabular}{llll} 
& \multicolumn{3}{c}{ Associated } \\
Sequence & Age set name & term(s) & Gloss \\
\hline 1 & nõzö'u & nõzö & Traditional maize \\
2 & abare'u & abare & Pequi fruit (Caryocar brasiliense) \\
3 & sada'ro & dazada'ro & (Bad) breath \\
4 & ainarowa & anhana & Feces \\
5 & hötörã & hötörã & Oscar fish (Astronotus spp.) \\
6 & airere & airere & Babassu palm (Orbignya phalerata) \\
7 & êtẽpá & êtẽpá & Scarce stone (used as mortar or pestle) \\
8 & tirowa & ti or ti'a & Arrow or tick (arachnid) \\
\hline
\end{tabular}

